OPEN ACCESS

Edited by: Ana R. Freitas,

Universidade do Porto, Portugal

Reviewed by: Ana P. Tedim

Neiker Tecnalia, Spain

Dzung B. Diep,

Norwegian University of Life Sciences,

Norway

*Correspondence:

Pinglan Li

lipinglan@cau.edu.cn

Qingmao Shang

shangqingmao@caas.cn

Specialty section:

This article was submitted to Antimicrobials, Resistance

and Chemotherapy,

a section of the journal

Frontiers in Microbiology

Received: 03 December 2018 Accepted: 25 February 2019

Published: 15 March 2019

Citation:

Qin Y, Wang Y, He Y, Zhang Y, She Q, Chai Y, Li P and Shang Q (2019) Characterization of Subtilin L-Q11, a Novel Class I Bacteriocin Synthesized by Bacillus subtilis L-Q11

Isolated From Orchard Soil.

Front. Microbiol. 10:484.

doi: 10.3389/fmicb.2019.00484

\section{Characterization of Subtilin L-Q11, a Novel Class I Bacteriocin Synthesized by Bacillus subtilis L-Q11 Isolated From Orchard Soil}

\author{
Yuxuan Qin',2, Yao Wang', Yinghao $\mathrm{He}^{2}$, Ying Zhang', Qianxuan She'2, Yunrong Chai', \\ Pinglan $\mathrm{Li}^{1 *}$ and Qingmao Shang ${ }^{3 *}$
}

${ }^{1}$ Beijing Advanced Innovation Center for Food Nutrition and Human Health, College of Food Science and Nutritional Engineering, Key Laboratory of Functional Dairy, China Agricultural University, Beijing, China, ${ }^{2}$ Department of Biology, Northeastern University, Boston, MA, United States, ${ }^{3}$ Key Laboratory of Biology and Genetic Improvement of Horticultural Crops, The Institute of Vegetables and Flowers, Chinese Academy of Agricultural Sciences, Beijing, China

Bacteriocins are peptides or proteins synthesized by bacterial ribosomes that show killing or inhibitory activities against different groups of bacteria. Bacteriocins are considered potential alternatives to traditional antibiotics, preservatives in pharmaceutical and food industries. A strain L-Q11 isolated from orchard soil was phylogenetically characterized as Bacillus subtilis based on 16S rRNA gene sequencing analysis. A novel class I bacteriocin (Subtilin L-Q11), was identified and purified from L-Q11 cell-free supernatant in a four-step procedure, including salt precipitation, cation exchange, gel filtration, and reverse-phase high-performance liquid chromatography (RP-HPLC). The molecular mass (3,552.9 Da) of this novel bacteriocin was determined by Matrix-assisted laser desorption/ionization time-of-flight mass spectrometry (MALDITOF-MS). The purified Subtilin L-Q11 exhibited optimal features in $\mathrm{pH}$ tolerance, thermostability, and sensitivity to proteases. Further, Subtilin L-Q11 showed inhibitory activities against a number of bacteria including some human pathogens and food spoilage bacteria, in particular Staphylococcus aureus. All these important features make this novel bacteriocin a potential candidate for the development of a new antibacterial drug or food preservative in the future.

Keywords: Subtilin L-Q11, Bacillus subtilis, bacteriocin, antibacterial activity, antibacterial mechanism

\section{INTRODUCTION}

Bacillus subtilis is a Gram-positive, spore-forming soil bacterium, which is known to produce more than twenty different, structurally diverse antimicrobial compounds (Stein, 2005). The majority of these compounds are peptide-based antibiotics. There are two principal synthetic pathways for biosynthesis of peptide-based antibiotics in B. subtilis: (i) non-ribosomal synthesis of peptides by non-ribosomal peptide synthetases (NRPSs), and (ii) ribosomally synthesized antimicrobial peptides (Giessen and Marahiel, 2012).

Bacteriocins are ribosomally synthesized peptide antibiotics, which show antagonistic activities toward different bacteria, especially to those that are genetically close to the producing strains 
(Klaenhammer, 1988). Bacteriocins are often employed as a weapon by the producing bacteria to compete and protect themselves in the natural environment. In the food industry, bacteriocins produced by lactic acid bacteria have long been applied in food preservation (Tagg et al., 1976). Bacteriocins also demonstrate great potentials as antimicrobial compounds in pharmaceutical, agricultural, and biochemical engineering industries (Dischinger et al., 2014). Bacteriocins have become more popular in recent years due to their therapeutic effects in treating bacterial infection, even against certain multidrug resistant bacteria (Garneau et al., 2002; Cotter et al., 2005). Furthermore, compared to chemically synthesized traditional antibiotics or food preservatives, bacteriocins present low toxicity toward human hosts because human cells do not possess a receptor recognized by bacteriocins (Kanmani et al., 2013; Yang et al., 2014). Bacteriocins were originally only found to be synthesized by Lactobacillus. It is now believed that more than $99 \%$ of bacteria can produce at least one type of bacteriocins, however, the majority of them are yet to be identified (Riley and Wertz, 2002).

An average of 4 and $5 \%$ of the B. subtilis genome is believed to be involved in the biosynthesis of various antimicrobial compounds (Stein, 2005). Thus, species from the Bacillus genus represent a great pool for screen and discovery of novel bacteriocins (Phelan et al., 2013). Based on distinct structural and functional characteristics, bacteriocins can be divided into different classes. Class I bacteriocins are also named lantibiotics. Most of the bacteriocins produced by Bacillus species belong to the class I bacteriocins (Singh et al., 2012).

In this study, we purified and characterized Subtilin L-Q11, a novel class I bacteriocin from B. subtilis L-Q11, a strain isolated from the orchard soil in Beijing, China. We demonstrated that this new bacteriocin has great potential to be used as a biologically synthesized antibiotic or food preservative in agricultural field and food industry. We also investigated the mode of action of this novel bacteriocin against the bacterial pathogen S. aureus ATCC 29213.

\section{MATERIALS AND METHODS}

\section{Bacterial Strains and Growth Conditions}

The spore-forming strain L-Q11 is a bacteriocin-producing bacterium isolated from the orchard soil in Beijing, China. Briefly, in order to isolate the spore-forming bacteria from natural environment. Soil samples from orchard was heated to kill non-spore-forming mesophiles, and then plated on rich media after dilution by sterilized water and incubated aerobically at $30^{\circ} \mathrm{C}$. Thermophiles would not grow at this temperature, and anaerobic spore-formers (e.g., Clostridium) will not grow aerobically. Other mesophilic aerobic endospore-formers (e.g., Heliospirillum) are phototrophic, scarce, and require lots of light for growth.

Bacillus subtilis was grown in Luria-Bertani (LB) broth at $37^{\circ} \mathrm{C}$ under the shaking condition (200 rpm). Staphylococcus aureus 29213 was used as an indicator strain for antibacterial activities of the Subtilin L-Q11 and it was also cultured in LB broth at $37^{\circ} \mathrm{C}$.

\section{Phylogenetic Characterization of the Strain L-Q11}

The bacteriocin-producing $B$. subtilis strain was phylogenetically identified by $16 \mathrm{~S}$ rRNA gene sequencing analysis. Briefly, the genomic DNA of L-Q11 was prepared by using a bacterial genomic extraction kit (TianGen, Beijing, China) according to the manufacturer's instructions. A region in the 16s rRNA gene was amplified by PCR using two universal primers (27F: 5'-AGAGTTTGATCMTGGCTCAG-3' and 1492R: $5^{\prime}$ TACGGYTACCTTGTTACGACTT-3') (Lane, 1991). Thermal cycling consisted of initial denaturation at $95^{\circ} \mathrm{C}$ for $10 \mathrm{~min}$, followed by 30 cycles of denaturation at $95^{\circ} \mathrm{C}$ for $30 \mathrm{~s}$, annealing at $50^{\circ} \mathrm{C}$ for $1 \mathrm{~min}$, and elongation at $72^{\circ} \mathrm{C}$ for $1 \mathrm{~min}$, and finally, at $72^{\circ} \mathrm{C}$ for $10 \mathrm{~min}$ for completion. The PCR product was sent for sequencing after purification using GeneJET Gel Extraction Kit (QIAGEN, Germany). The sequencing result was blasted against the NCBI GenBank database ${ }^{1}$. If the similarity of the $16 \mathrm{~s}$ rRNA gene sequence of this strain valued $>97 \%$ when compared with a certain species, we considered that this strain belonged to this species.

\section{Crude Bacteriocin Preparation and Antibacterial Activity Assay}

Bacillus subtilis L-Q11 was inoculated in $50 \mathrm{~mL}$ of LB broth and grown overnight, $1 \%$ of the overnight culture was reinoculated into $1 \mathrm{~L}$ of $\mathrm{LB}$ broth and incubated at $37^{\circ} \mathrm{C}$ under the shaking condition at $200 \mathrm{rpm}$. Samples were collected every $4 \mathrm{~h}$ to record the medium $\mathrm{pH}$ and cell optical density (O.D.600). Meanwhile, cell-free supernatant (CFS) from each time point was used to test the antibacterial activity against an indicator strain (S. aureus ATCC 29213). Briefly, we centrifuged the culture samples at $12,000 \mathrm{rpm}$ for $15 \mathrm{~min}$ at $4^{\circ} \mathrm{C}$ to remove the cell pellets. The supernatant was filter-sterilized by passing through the Nalgene ${ }^{\mathrm{TM}}$ Rapid-Flow $^{\mathrm{TM}}$ Sterile Disposable Filter $(0.22 \mu \mathrm{m}$, Thermo Fisher Scientific, MA, United States) to obtain the CFS. The antibacterial activity of the crude bacteriocin in the CFS was determined by measuring the diameter of the inhibition zone with vernier caliper using S. aureus ATCC 29213 as an indicator strain. The antibacterial activity was presented as an arbitrary unit per milliliter of culture medium $(\mathrm{AU} / \mathrm{mL})$ and one $\mathrm{AU}$ was defined as the reciprocal of the highest 2-fold dilution exhibiting a clear zone of inhibition of the indicator strain (Deraz et al., 2005).

\section{Purification of Subtilin L-Q11}

CFS was first mixed with $70 \%(\mathrm{w} / \mathrm{v})$ ammonium sulfate at $4^{\circ} \mathrm{C}$ overnight under the continuous stirring and then centrifuged at $9,000 \mathrm{~g}$ for $20 \mathrm{~min}$ at $4^{\circ} \mathrm{C}$. After that, the precipitation was collected and dissolved in $10 \mathrm{~mL}$ of PBS buffer $(\mathrm{pH}$ 7.0). The crude extract obtained after ammonium sulfate precipitation was applied onto the CM Sepharose Fast Flow cation-exchange column $(16 \mathrm{~mm} \times 200 \mathrm{~mm}$, GE, Sweden $)$ equilibrated and washed with $50 \mathrm{mM}$ PBS ( $\mathrm{pH}$ 6.0) linked to AKTA purifier 100 system (GE, Sweden). The elution was

\footnotetext{
${ }^{1}$ http://www.ncbi.nlm.nih.gov/BLAST
} 
carried out by a linear gradient (from 0 to $1 \mathrm{M}$ of $\mathrm{NaCl}$ ) in the same buffer as equilibration for $60 \mathrm{~min}$ at a flow rate of $1 \mathrm{~mL} / \mathrm{min}$ and monitored by an $\mathrm{UV}$ detector at the wavelength of $280 \mathrm{~nm}$.

The active fractions obtained from the last step of purification were loaded onto a Sephadex G-10 (12 mm × $200 \mathrm{~mm}, \mathrm{GE}$, Sweden) column equilibrated with PBS buffer ( $\mathrm{pH}$ 6.0) and connected to an AKTA purifier 100 system (GE, Sweden). The elution was carried out at the flow rate of $0.5 \mathrm{~mL} / \mathrm{min}$ and recorded by UV at the wavelength of $280 \mathrm{~nm}$ by the same buffer.

The active fractions from above were applied onto a reverse phase high-performance liquid chromatography (RP-HPLC) system (Agilent, CA, United States) equipped with C18 reversephase column $(5 \mu \mathrm{m}, 4.6 \mathrm{~mm} \times 250 \mathrm{~mm}$, Agilent, United States) for further purification. The elution was performed using 5-95\% linear gradient of acetonitrile containing $0.1 \%$ trifloroacetic acid (TFA) with a flow rate of $1 \mathrm{~mL} / \mathrm{min}$ for $30 \mathrm{~min}$ and monitored by $\mathrm{UV}$ at the wavelength of $280 \mathrm{~nm}$.

The collected fractions were concentrated and tested for antibacterial activities as described by An et al. (2017), and then stored at $-80^{\circ} \mathrm{C}$. The BCA kit (Thermo Fisher Scientific, MA, United States) was used for the protein concentration analysis.

\section{Molecular Weight and Amino Acid Sequence Determination}

The molecular mass of the bacteriocin in the active fractions obtained after the HPLC purification were determined by matrixassisted laser desorption ionization-time-of-flight (MALDITOF) mass spectrometry (MS) (Applied Biosystems, Foster city, CA, United States) in the positive mode. The active fraction was mixed together with the same volume of matrix solution contained $0.1 \%(\mathrm{v} / \mathrm{v})$ of $\alpha$-cyano-4-hydroxycinnamic acid (CHCA, Sigma, United States) dissolved in trifluoroacetic acid and $50 \%(\mathrm{v} / \mathrm{v})$ of acetonitrile. For the MALDI analysis, $1 \mu \mathrm{l}$ of the mixture was deposited directly onto the MALDI plate for drying. For identifying $\mathrm{N}$-terminal amino sequence of Sublitin L-Q11, the purified Sublitin L-Q11 electrophoresed by SDS-PAGE was transferred to PVDF membrane (Millipore, United States). Residue amino sequence identified by Edman degradation was then compared with other published bacteriocin sequences by NCBI blast.

\section{Antimicrobial Spectrum Assay}

To investigate the antimicrobial spectrum of Subtilin L-Q11, partially purified Subtilin L-Q11 preparation from cation exchange chromatography was adjusted to $\mathrm{pH} 6.0$ by using $1 \mathrm{M} \mathrm{NaOH}$, and the spectrum of antibacterial activity was determined against a series of food-borne and foodspoilage pathogens (Table 1) by using the pour plate method described by An et al. (2017).

\section{Determination of Physicochemical Characteristics of Subtilin L-Q11}

To evaluate the physicochemical characteristics of Subtilin L-Q11, proteolytic, thermal, $\mathrm{pH}$, and surfactant sensitivities of the bacteriocin were tested. To test the proteolytic sensitivity of
TABLE 1 | Antibacterial spectrum of Subtilin L-Q11.

\begin{tabular}{|c|c|c|}
\hline Indictor strain & Source & $\begin{array}{l}\text { Diameter of inhibition } \\
\text { zone }(\mathrm{mm})\end{array}$ \\
\hline \multicolumn{3}{|l|}{ Gram-positive bacteria } \\
\hline $\begin{array}{l}\text { Bacillus amyloliquefaciens } \\
\text { ATCC } 15841\end{array}$ & ATCC & $16.2 \pm 0.2$ \\
\hline B. amyloliquefaciens L-S60 & Qin et al., 2015b & $16.1 \pm 0.3$ \\
\hline B. amyloliquefaciens L-H15 & Qin et al., 2015a & $16.0 \pm 0.3$ \\
\hline B. cereus ATCC 14579 & ATCC & $16.4 \pm 0.2$ \\
\hline Lactococcus lactis NZ9000 & Linares et al., 2010 & $9.4 \pm 0.2$ \\
\hline L. lactis MG1363 & Linares et al., 2010 & $9.1 \pm 0.3$ \\
\hline Lactobacillus plantarum S-35 & Wang et al., 2018 & $10.3 \pm 0.2$ \\
\hline L. plantarum $\gamma-35$ & Wang et al., 2018 & $11.0 \pm 0.3$ \\
\hline $\begin{array}{l}\text { Staphylococcus aureus ATCC } \\
29213\end{array}$ & ATCC & $16.4 \pm 0.4$ \\
\hline S. aureus ATCC 43300 & ATCC & $16.3 \pm 0.4$ \\
\hline S. aureus ATCC 26112 & ATCC & $16.1 \pm 0.4$ \\
\hline $\begin{array}{l}\text { Enterococcus faecalis ATCC } \\
29212\end{array}$ & ATCC & $16.2 \pm 0.4$ \\
\hline E. faecalis ATCC 51299 & ATCC & $8.2 \pm 0.2$ \\
\hline E. faecalis M2 & Wang et al., 2018 & $6.3 \pm 0.5$ \\
\hline \multicolumn{3}{|l|}{ Gram-negative bacteria } \\
\hline Escherichia coli $\mathrm{DH} 5 \alpha$ & Takara & 0 \\
\hline E. coli BL21 & Takara & 0 \\
\hline E. coli BW25113 & Grenier et al., 2014 & 0 \\
\hline E. coli JM109 & Takara & 0 \\
\hline \multicolumn{3}{|l|}{ Fungi } \\
\hline Saccharomyce cerevisiae & Wang et al., 2018 & 0 \\
\hline Pichia pastoris GS115 & Thermo Fisher Scientific & 0 \\
\hline
\end{tabular}

Subtilin L-Q11, different types of proteases including Pepsin $(\mathrm{pH}$ 3.0), Papain ( $\mathrm{pH}$ 6.5), Proteinase $\mathrm{K}$ ( $\mathrm{pH} 7.5)$, Trypsin ( $\mathrm{pH} 7.6$ ), and Chymotrypsin ( $\mathrm{pH} 7.8$ ), were incubated with the bacteriocin at a final concentration of $1 \mathrm{mg} / \mathrm{mL}$ for $3 \mathrm{~h}$. After incubation, the mixture was heated to $100^{\circ} \mathrm{C}$ for $5 \mathrm{~min}$ to terminate the enzymatic reaction. To test its thermal sensitivity, Subtilin L-Q11 was heated to 60,80 , and $100^{\circ} \mathrm{C}$, respectively, for 15 and $30 \mathrm{~min}$, and $121^{\circ} \mathrm{C}$ for $20 \mathrm{~min}$. The $\mathrm{pH}$ tolerance of the bacteriocin was measured by adjusting the $\mathrm{pH}$ of the buffer to a range of 2-11 using $5 \mathrm{M} \mathrm{NaOH}$ or $\mathrm{HCl}$ for $2 \mathrm{~h}$. Various chemical reagents, including $1 \%(\mathrm{v} / \mathrm{v})$ of ethylene diamine tetraacetic acid (EDTA), Tween 20, Tween 80 , and urea were incubated with the bacteriocin for $5 \mathrm{~h}$ at $37^{\circ} \mathrm{C}$ to determine its tolerance to the chemical reagents.

After each treatment from above, the antibacterial activity of the residual bacteriocin was measured and compared to the untreated bacteriocin to estimate the loss of the bacteriocin after each of the above treatments.

\section{Antibacterial Activity of Subtilin L-Q11 Against S. aureus}

In order to determine the action mode of Subtilin L-Q11, S. aureus ATCC 29213 was cultured overnight in TSB broth (BD Biosciences, United States) at $37^{\circ} \mathrm{C}$ with shaking (200 rpm). Cells were spun down and readjusted to a final density of 
$10^{7} \mathrm{CFU} / \mathrm{mL}$ by using $0.9 \%$ sterile $\mathrm{NaCl}$. The final concentration of the bacteriocin was adjusted to $64 \mu \mathrm{g} / \mathrm{mL}$ ( MIC $_{50}$ of Subtilin L-Q11 against S. aureus ATCC 29213) and the sample with the same amount of TSB broth was used as a control. All the samples for the test were incubated at $37^{\circ} \mathrm{C}$ under shaking (200 rpm) for $5 \mathrm{~h}$. The cell optical density (O.D.600) and the number of viable cells were measured every hour (Deraz et al., 2007).

\section{Scanning and Transmission Electron Microscopy}

In order to observe the morphological changes of $S$. aureus ATCC 29213 cells after treated with Subtilin L-Q11, scanning electron microscopy (SEM) was used. S. aureus ATCC 29213 cells $\left(1 \times 10^{7} \mathrm{CFU} / \mathrm{ml}\right)$ in $\mathrm{LB}$ broth were mixed with $256 \mu \mathrm{g} / \mathrm{mL}$ $\left(4 \times \mathrm{MIC}_{50}\right)$ of Subtilin L-Q11 and incubated at $37^{\circ} \mathrm{C}$ for 1,2 , and $3 \mathrm{~h}$, respectively. Cells without bacteriocin treatment were set as a control. Cells in both the bacteriocin treatment and control groups were collected by centrifugation and washed with phosphate buffer (0.1 M, pH 7.0). Cells for SEM observation were fixed for $4 \mathrm{~h}$ in $2.5 \%$ glutaraldehyde at $4^{\circ} \mathrm{C}$ and then dehydrated with gradient ethanol solutions $(30,50,80,90$, and $100 \%)$. After that, ethanol was replaced by $100 \%$ tertiary butyl ethanol. Cells were then freeze-dried (Wheeler et al., 1975), coated with gold, and imaged using a FEI Quanta 200 SEM.

For observation of intracellular differences between cells in the Subtilin L-Q11 treatment and control groups, transmission electron microscopy was performed as previously described (Yamanaka et al., 2005) with minor modifications. Briefly, cells were fixed as described above. After that, samples for imaging were osmicated in $2 \%$ osmium tetroxide at $4^{\circ} \mathrm{C}$ for $4 \mathrm{~h}$, and then were dehydrated with gradient ethanol solutions as described above. Embedding was performed in epoxy resin at $60^{\circ} \mathrm{C}$ for $48 \mathrm{~h}$. The sections were then coated with an amorphous carbon film and stained with $2 \%$ uranyl acetate and lead citrate. Ultrastructure observation and photomicrographs were then carried out using a JEM-1200EX TEM (Japan Electronics Co., Ltd., Japan).

\section{Statistical Analysis}

Data in this study were presented as means \pm standard deviations (SD). One-way analysis of variance (ANOVA) and Duncan's multiple range test of the data were carried out by SPSS 23.0, and $p<0.05$ was considered statistically significant. All the experiments were preformed in triplicate.

\section{RESULTS}

\section{Phylogenetic Characterization of the Strain L-Q11}

We performed BLAST search using the DNA sequence of the $16 \mathrm{~S}$ rRNA gene of L-Q11 as a query against the NCBI GenBank database. Our result indicated that the $16 \mathrm{~S}$ rRNA gene sequence of L-Q11 showed extremely high similarity (identity $\geq 99 \%$, E value $=0)$ to $B$. subtilis. We finally classified the strain $\mathrm{L}-\mathrm{Q} 11$ as B. subtilis.

\section{Dynamic Production of the Antibiotic Against $S$. aureus by $B$. subtilis L-Q11}

The dynamic profile of antibiotic production by $B$. subtilis L-Q11 during growth was investigated when cells were cultured in LB broth under the shaking condition (200 rpm) at $37^{\circ} \mathrm{C}$. The inhibitory activity of the CFS against growth of the indicator strain S. aureus ATCC 29213 was used as a measurement of antibiotic production. The growth profile of L-Q11 showed that the culture transitioned to early exponential phase $2 \mathrm{~h}$ after inoculation, entered stationary phase at $8 \mathrm{~h}$ and remained in stationary phase until end of the experiment (Figure 1). The antibacterial activity in the CFS against S. aureus ATCC 29213 was evaluated by measuring the diameter of the inhibition zone. The bacteriocin begun to be produced after cells entered early stationary phase $(8 \mathrm{~h})$ and reached maximum at $20 \mathrm{~h}$. Although the antibacterial capacity in the CFS produced by L-Q11 begun to decrease after $20 \mathrm{~h}$, it showed inhibitory activity during the entire stationary phase (Figure 1). The $\mathrm{pH}$ of the broth was also measured once every $4 \mathrm{~h}$ during the entire experiment. We found that the $\mathrm{pH}$ of the medium dropped from 7.0 to 5.2 during the exponential phase and then went back to almost 7.0 (Figure 1). The observed $\mathrm{pH}$ changes in the medium indicate that the metabolic capacity of this strain meets the basic requirement of industrial fermentation.

\section{Purified Bacteriocin From L-Q11 Showed Strong Bacterial Inhibitory Activity}

The CFS collected after $20 \mathrm{~h}$ of incubation under the shaking condition was used for bacteriocin extraction and purification by a four-step procedure as described in the Methods. The yield and characteristics of the bacteriocin after each purification step were shown in Table 2. The crude bacteriocin in the CFS was first extracted by ammonium sulfate precipitation and approximately 2 -fold enrichment of the bacteriocin was achieved at this stage as measured by the inhibitory activity against S. aureus ATCC 29213 (Table 2). For further purification the crude bacteriocin was subjected to a SP-Sepharose Fast Flow cation exchange column. Five main peaks were obtained and separated into five different fractions at this stage. We then tested all five fractions and found that only fraction 5 showed antibacterial activity (Figures 2Aa,b). In addition, we achieved 41-fold enrichment after this step; the antibacterial activity of bacteriocin increased from 1,500 to $37,000 \mathrm{AU} / \mathrm{mg}$ against the indicator strain. Next, the active fraction (fraction 5) was injected into a Sephadex G-10 gelfiltration chromatography for the subsequent purification step. During this step, two separate peaks were observed by measuring the absorbance at the wavelength of $220 \mathrm{~nm}$. However, only fraction 1 retained the antibacterial activity (Figures $2 \mathbf{B a}, \mathbf{b}$ ). Meanwhile, the bacteriocin activity increased 80 -fold after this purification step. RP-HPLC was applied in the final purification step of the bacteriocin. The corresponding fraction to this peak showed a strong antibacterial activity against $S$. aureus ATCC 29213 (Figures 2Ca,b). In summary, after series of purification steps, the antibacterial activity of the bacteriocin 


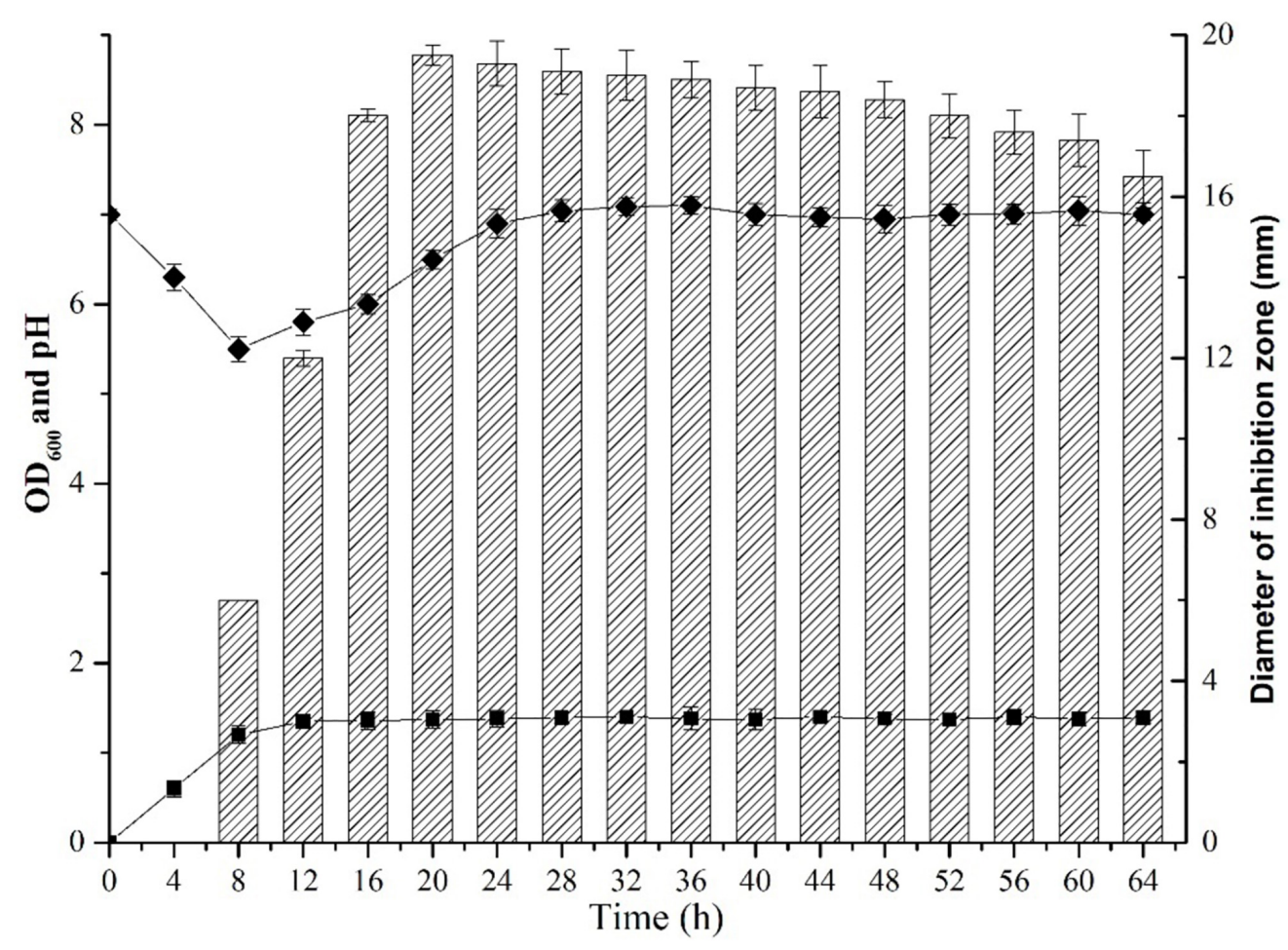

FIGURE 1 | Growth and dynamics of bacteriocin production by B. subtilis L-Q11. "

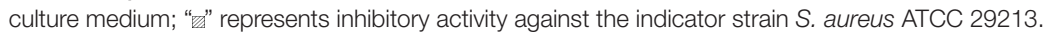

TABLE 2 | Purification of the bacteriocin produced by L-Q11.

\begin{tabular}{|c|c|c|c|c|c|c|}
\hline Purification Stage & Volume (mL) & Total protein (mg) & Total activity (AU) & Specific activity (AU/mg) & Purification fold & Recovery (\%) \\
\hline Culture supernatant & 200 & 1156 & $1,024,000$ & 885 & 1 & 100 \\
\hline Ammonium sulfate precipitation & 20 & 531 & 820,000 & 1,500 & 2 & 80 \\
\hline SP-sepharose fast flow & 5 & 17 & 612,000 & 37,000 & 41 & 35 \\
\hline Sephadex G10 & 1 & 4 & 313,000 & 71,000 & 80 & 13 \\
\hline RP-HPLC & 0.3 & 1 & 104,000 & 104,000 & 117 & 2 \\
\hline
\end{tabular}
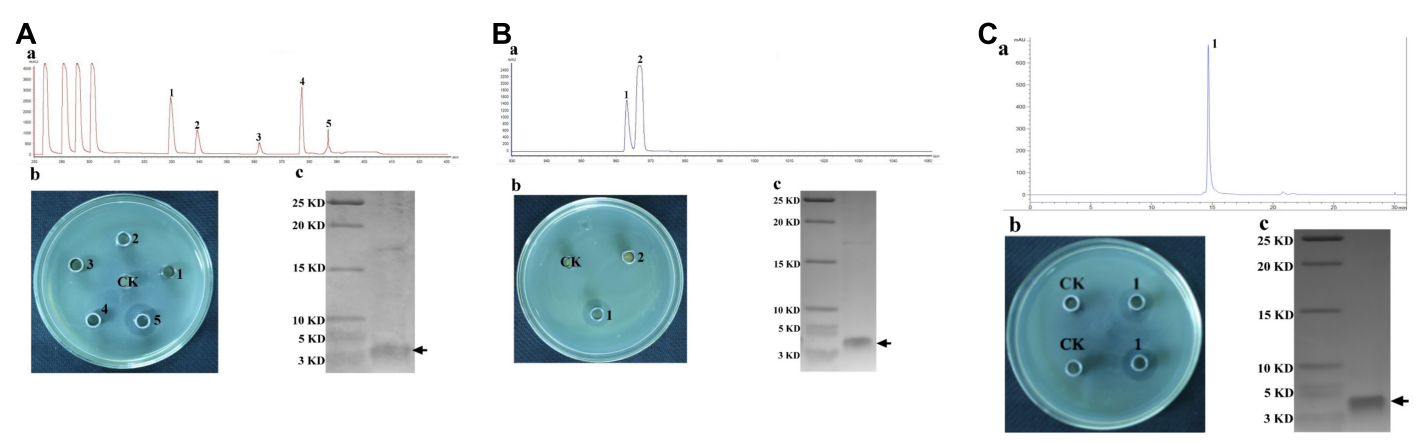

FIGURE 2 | Purification of Subtilin L-Q11 by chromatography. (A) cation exchange column; (B) gel filtration chromatography; (C) RP-HPLC. (a) process of purification; (b) the assay of antibacterial activity against the indicator strain from the absorbance peaks versus CK (control) by agar well diffusion assay; (c) Tricine-SDS-PAGE of the purified active fraction. The arrows indicate the active fraction after each step of purification on Tricine-SDS-PAGE gel. 
increased 117-fold compared to that in the initial CFS, reaching 104,000 $\mathrm{AU} / \mathrm{mg}$.

\section{Molecular Mass and Amino Acid Sequence Determination}

The molecular mass of the purified bacteriocin produced by $B$. subtilis L-Q11 is $3,552.9 \mathrm{Da}$ as determined by MALDI-TOF MS (Figure 3A). The molecular mass of the bacteriocin produced by $B$. subtilis L-Q11 is different from any of the published bacteriocins. According to the genome sequence analysis of $B$. subtilis L-Q11, the entire amino acid sequence of the bacteriocin was MSKFDDFDLDVV KVSKQDSKITPQWKSESVCTPGCVTGILQTCFLQSITCNCRL SK. Aligned with published bacteriocins from Bacillus spp. (Barbosa et al., 2015), bacteriocin produced by B. subtilis L-Q11 showed highly similarity to class I bacteriocin but was not identical (Figure 3B). We thus believe that it is a novel Class I bacteriocin and named it Subtilin L-Q11.

\section{Subtilin L-Q11 Showed a Broad Range of Antibacterial Activities}

Subtilin L-Q11 showed a wide range of an antibacterial spectrum (Table 1). It could inhibit the growth of various Gram-positive bacteria including Bacillus amyloliquefaciens, Lactococcus lactis, Lactobacillus plantarum, Staphylococcus aureus, and Enterococcus faecalis. Some of them are important spoilage bacteria in food industry and human pathogens, such as S. aureus ATCC
29213 and species from Bacillus genus. However, it showed no inhibitory activity on any of the tested Gram-negative bacteria and fungi (Table 1).

\section{Subtilin L-Q11 Demonstrated Desirable Thermostability, pH Tolerance, Resistance to Chemical Reagents, and Sensitivity to Proteases}

We next tested several physicochemical characteristics of Subtilin L-Q11, including thermostability, $\mathrm{pH}$ tolerance, resistance to chemical reagents, and sensitivity to proteases. In thermostability test, more than $97 \%$ of the bacterial inhibitory activity was retained after 15 or $30 \mathrm{~min}$ of heat treatment at 60 or $80^{\circ} \mathrm{C}$, respectively. Further, the activity was decreased significantly $(p<0.05)$ when under the treatments of $100^{\circ} \mathrm{C}$ for 15 and $30 \mathrm{~min}$, or at $121^{\circ} \mathrm{C}$ for $20 \mathrm{~min}$, but there was still more than $54 \%$ of activity retained (Figure 4A). Subtilin L-Q11 retained more than $90 \%$ of the antimicrobial activity in buffers with the $\mathrm{pH}$ ranged from 2 to 7 . Although in the buffer of $\mathrm{pH} \mathrm{8-10,} \mathrm{the} \mathrm{antimicrobial}$ activity of Subtilin L-11 decreased significantly $(p<0.05)$, it still showed some activity at pH 10 (27.83\%) (Figure 4B). We also tested the impact of several detergents on the activity of the bacteriocin. We found that Subtilin L-Q11 showed great tolerant character after $3 \mathrm{~h}$ treatment by $1 \%(\mathrm{~V} / \mathrm{V})$ of Tween-20, Tween80, Urea and EDTA. It still retained 97.9, 97.2, 95.9 and 98.3\% of the activities after treated by above detergents, respectively, (Figure 4C). The activity of the bacteriocin from L-Q11 was
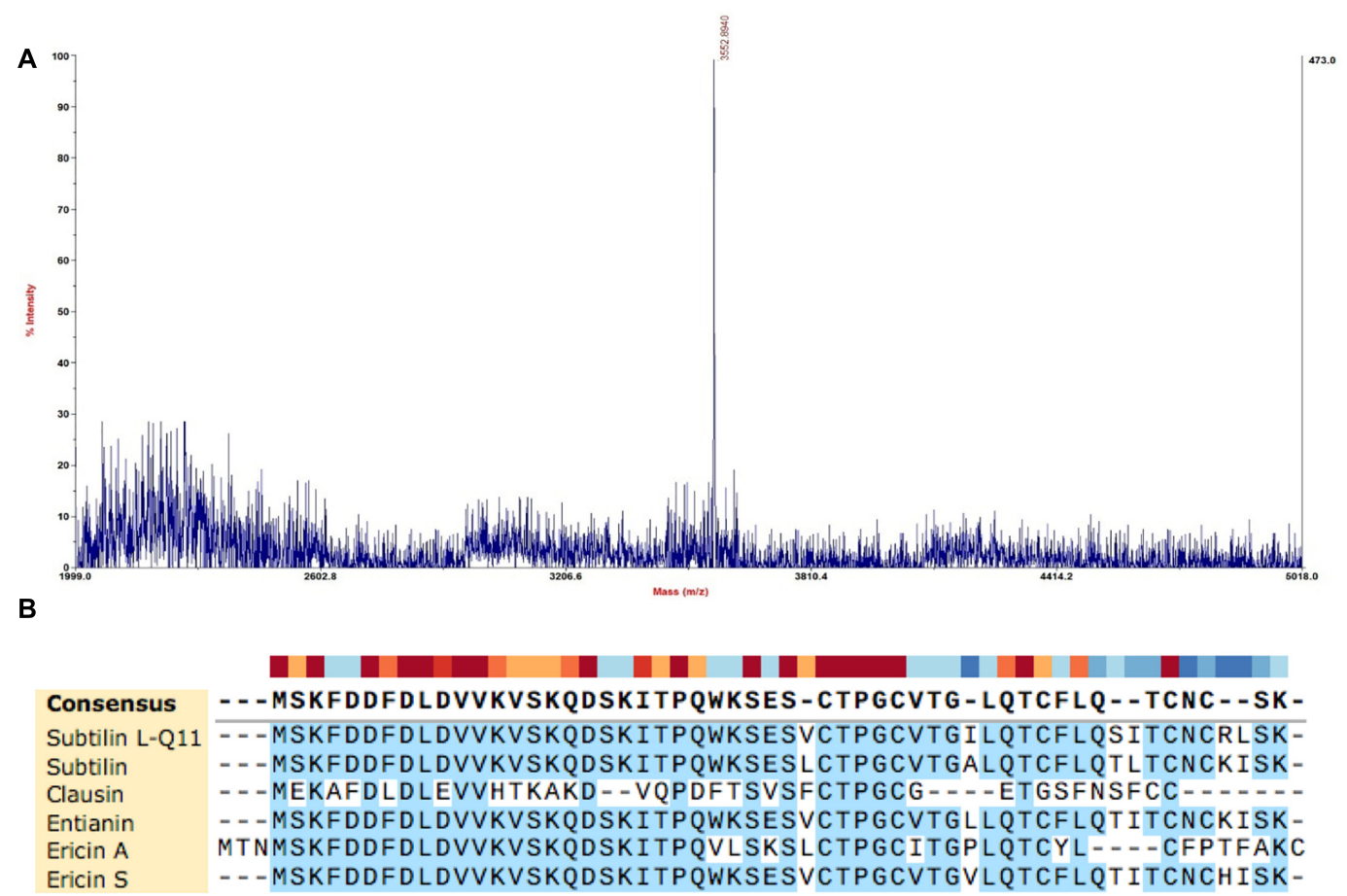

FIGURE 3 | Molecular mass determination and amino acid sequence alignment of Subtilin L-Q11. (A) The mass spectrum shown corresponded to the absorbance peak after purification using RP-HPLC in Figure 2C. (B) Alignment of published class I bacteriocins from Bacillus spp. and Subtilin L-Q11. Alignments were obtained by SnapGene V4.2.6 with default settings. 

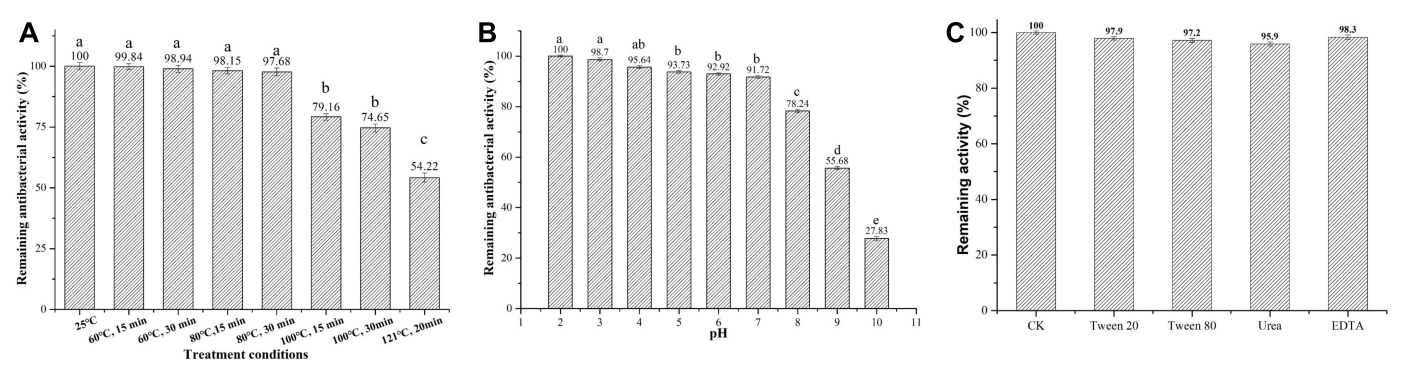

FIGURE 4 | Subtilin L-Q11 demonstrated optimal thermostability, $\mathrm{pH}$ tolerance, and resistance to chemical reagents. The effects of pH (A), temperature (B) and surfactant (C) on the bacteriocin activity produced by L-Q11 were assayed. Relative ratios in percentages were applied to represent retained antibacterial activities of the bacteriocin samples after various treatments when compared to the untreated control group. "abcde" indicates the significant difference among different conditions, the same letter represents no significant differences among those groups and different letters represents significant differences $(p<0.05)$ among those groups.

totally lost after treatment by any of the three important human digestive proteases, trypsin, chymotrypsin, and pepsin. Also, the commonly used proteinase $\mathrm{K}$ could completely eliminate the activity of bacteriocin.

\section{Subtilin L-Q11 Induced Serious Morphological and Intracellular Changes in S. aureus Cells}

We were interested in better understanding the inhibitory mechanism of Subtilin L-Q11 against S. aureus ATCC 29213. Upon treatment of Subtilin L-Q11 for $3 \mathrm{~h}$, the viable number of
S. aureus ATCC 29213 cells dropped from 8 to $6[\log (\mathrm{cfu} / \mathrm{mL})]$ and the optical density of the culture decreased from 1 to 0.25 (O.D.600) (Figure 5). This implies that Subtilin L-Q11 induced cell lysis in S. aureus ATCC 29213.

To demonstrate in detail, the potential morphological and intracellular changes in S. aureus ATCC 29213 cells upon cell lysis caused by Subtilin L-Q11, Scanning Electron Microscope (SEM) and Transmission Electron Microscope were used. Morphological changes in S. aureus ATCC 29213 cells were shown in Figure 6. Compared to the regular shape and smooth surface of cells in the control group (Figure 6A), S. aureus ATCC 29213 cells treated with $256 \mu \mathrm{g} / \mathrm{mL}\left(4 \times \mathrm{MIC}_{50}\right)$

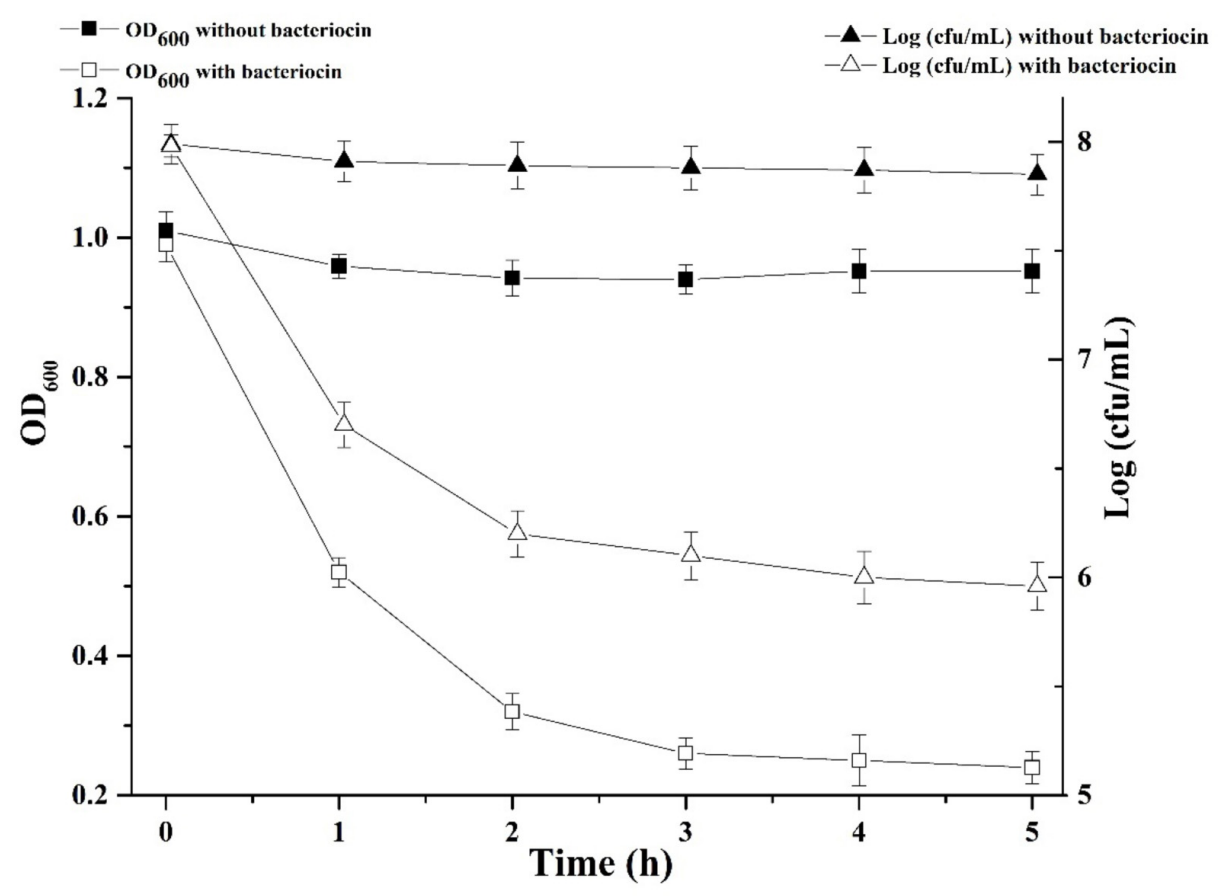

FIGURE 5 | Subtilin L-Q11 treatment triggered cell lysis in S. aureus. "А" represents viable cell count of untreated S. aureus ATCC 29213 ; " $\Delta$ " represents viable cell count of S. aureus ATCC 29213 with the treatment of bacteriocin; " $\mathbf{\square}$ " represents cell optical density at the wavelength of 600 nm (O.D.600) without bacteriocin treatment; " $\square$ " represents optical density at the wavelength of $600 \mathrm{~nm}$ with bacteriocin treatment. 
A

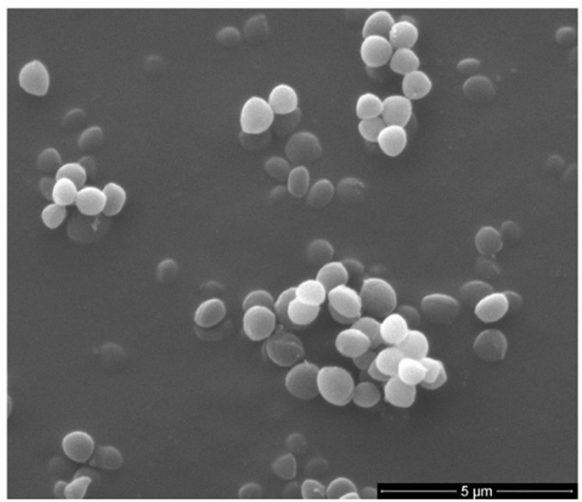

C

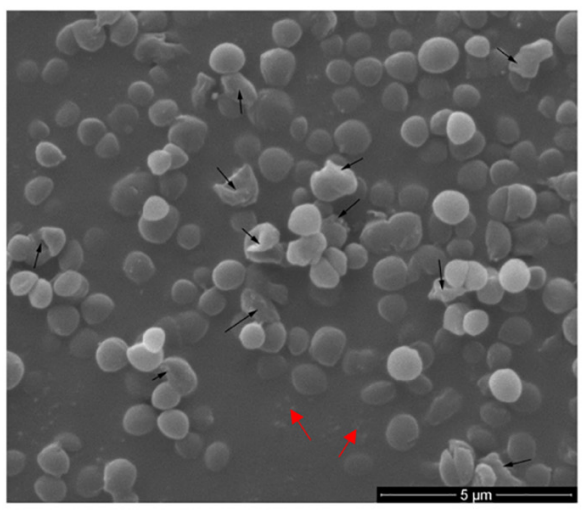

B

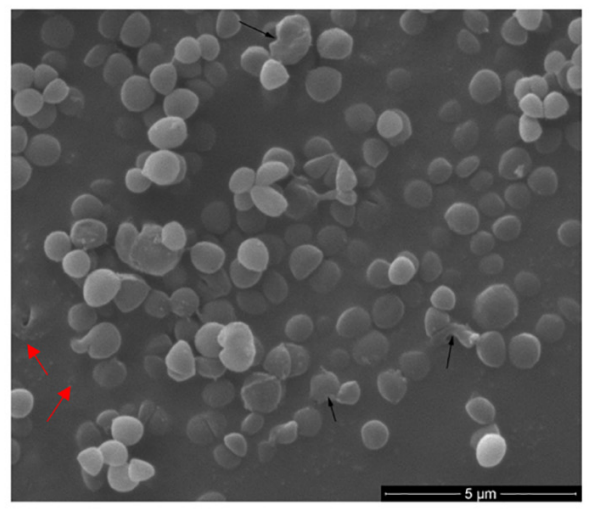

D

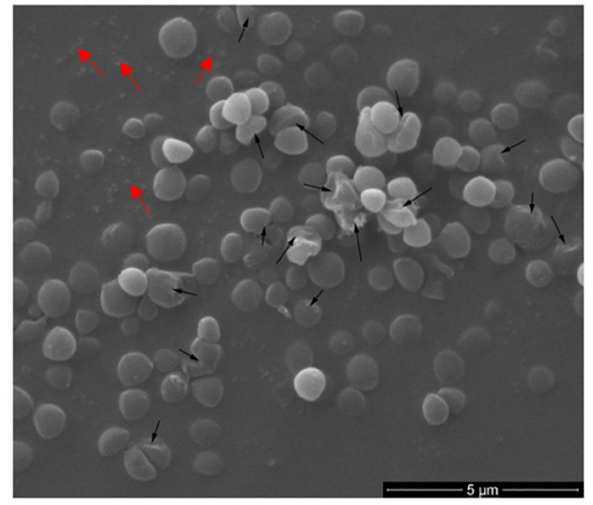

FIGURE 6 | Scanning electron microscopy of S. aureus cells treated by Subtilin L-Q11. (A) S. aureus ATCC 29213 cells from the untreated control group; (B-D) S. aureus ATCC 29213 cells treated with $256 \mu \mathrm{g} / \mathrm{mL}\left(4 \times \mathrm{MIC}_{50}\right)$ of Subtilin L-Q11 for 1, 2, and $3 \mathrm{~h}$, respectively. Scale bars: $500 \mathrm{~nm}$. Black arrows: the cell hollowness and membrane disruption; red arrows: cell fragments. For the sample preparation of TEM and SME, cell cultures were concentrated by centrifuging. During the sample preparation, large amount of the lysed cell (cell fragments) would lost.

Subtilin L-Q11 for $1 \mathrm{~h}$ showed slight hollowness on the surface (black arrows, Figure 6B). After exposed to the bacteriocin for 2 to $3 \mathrm{~h}$ (Figures 6C,D), the surface of cells showed more serious hollowness and clear membrane disruption (black arrows). Also fragments of lysed cell were seen in Figures 6B-D (red arrows). Moreover, the bacteriocin-induced deformation of S. aureus ATCC 29213 cells happened in a timerelated manner.

The intracellular changes of S. aureus ATCC 29213 cells treated with Subtilin L-Q11 were observed by TEM. Under TEM, cells in the untreated control group showed features characterized as typical cell wall, and intact and smooth cell membrane (Figure 7A). Also, the biomass and the seemingly genomic DNA were evenly distributed in the cytoplasm. In contrast, after exposure to $256 \mu \mathrm{g} / \mathrm{mL}\left(4 \times \mathrm{MIC}_{50}\right)$ Subtilin L-Q11 for $1 \mathrm{~h}$, the intracellular organization of cells was significantly disrupted, showing condensation of genomic DNA and vacuolization (Figure 7B). Moreover, the cytoplasm began to leak slightly (arrow 2 in Figure $7 \mathbf{B}$ ). When the exposure time was prolonged to $2 \mathrm{~h}$, although the entire cell structure was still largely retained, the seriously disrupted cell membrane was clearly visible as shown in Figure 7C. Also, loss of cytoplasm could be observed in the cells of the treatment group, and the leaked biomass from the cytoplasm could be observed around cell (arrow 1 in Figure $7 \mathrm{C}$ ). After $3 \mathrm{~h}$ of treatment by the bacteriocin, the cytoplasm of the treated cells showed a lower density compared to that of the cells in control group, probably due to the loss of solutes (Figure 7D). Also, a discontinuity and ruptured cell membrane surface of treated cells was shown (arrow 3 in Figure 7D). This indicates that these cells were already lysed. All these observations showed that Subtilin L-Q11 induced serious disruption of the intracellular organization of $S$. aureus ATCC 29213 cells.

\section{DISCUSSION}

In this study, we reported a novel bacteriocin, Subtilin L-Q11, synthesized by $B$. subtilis L-Q11 isolated from orchard soil that demonstrated great biophysical characteristics, which makes it a potential candidate as both an antibacterial compound and a food preservative. A four-step procedure consisting of ammonium sulfate precipitation, SP-sepharose Fast Flow, Sephadex G10 and RP-HPLC, was used for the 
A

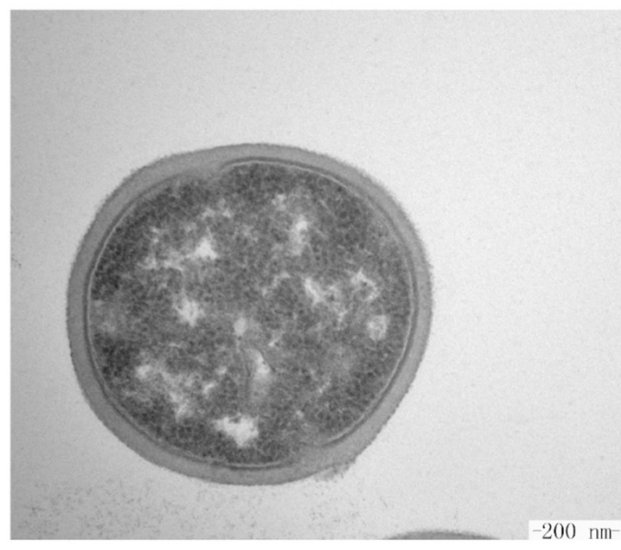

C

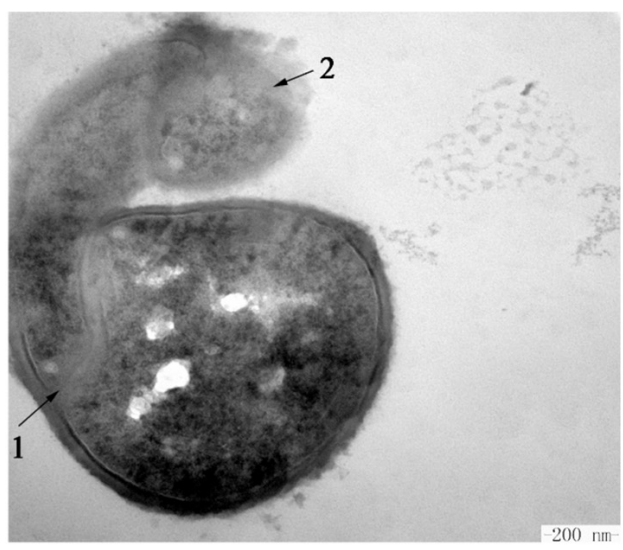

B

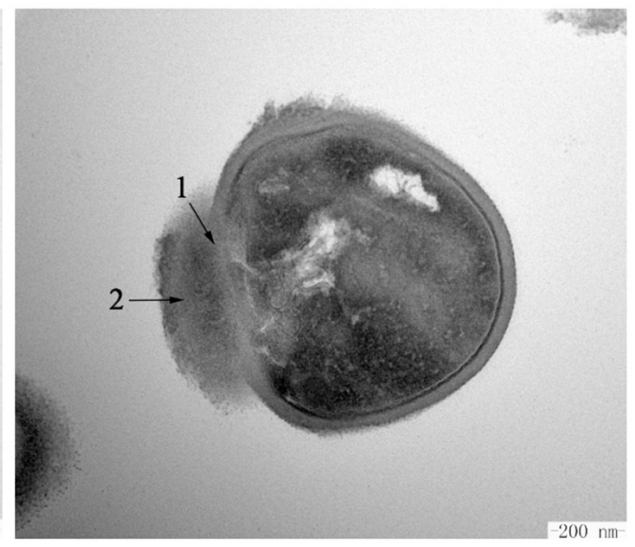

D

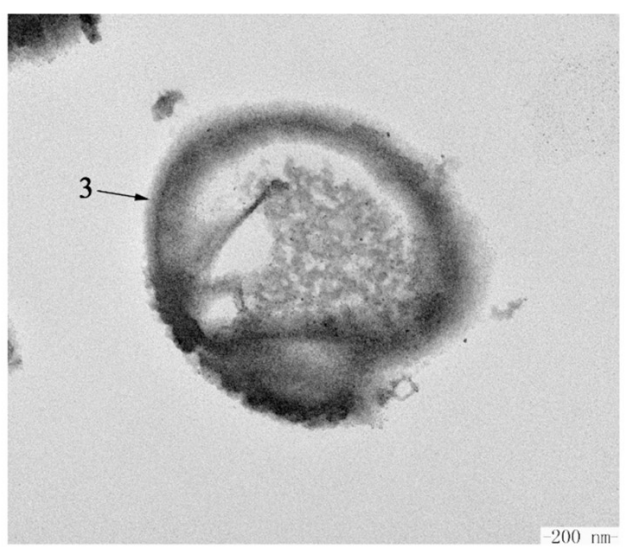

FIGURE 7 | Transmission electron microscopy of S. aureus cells treated by Subtilin L-Q11. (A) S. aureus ATCC 29213 cells from the untreated control group; (B-D) S. aureus ATCC 29213 cells treated with $256 \mu \mathrm{g} / \mathrm{mL}\left(4 \times \mathrm{MIC}_{50}\right.$ ) of Subtilin L-Q11 for 1, 2, and 3 h, respectively. Scale bars: 200 nm. Arrows numbered 1: the damaged cell membrane. Arrows numbered 2: the leaked intracellular substance. The arrow numbered 3: the ruptured cells.

purification of the bacteriocin. Subtilin L-Q11 retained strong antibacterial activity after purification. According to the genome sequence analysis, the entire amino acid sequence of the Subtilin L-Q11 was determined as MSKFDDFDLDVVKVSKQDSKITPQWKSESVCTPGCVTGILQ TCFLQSITCNCRLSK. The amino acid sequence is similar, but not identical, to the reported Class I bacteriocins (Barbosa et al., 2015). The molecular mass of the purified bacteriocin is 3,552.9 Da, determined by MS. This is different from other known bacteriocins, such as Sentianin ( $\mathrm{MW}=3446.6 \mathrm{Da})$ (Fuchs et al., 2011),Ericin S (MW = 3342.8 Da),Ericin A $(\mathrm{MW}=2987.7 \mathrm{Da})$ (Stein et al., 2002), Clausin $(\mathrm{MW}=2107.5 \mathrm{Da})$ (Bressollier et al., 2014), subtilomycin (MW = $3235 \mathrm{Da})$ (Phelan et al., 2013), Thuricin 4A-4 (MW = $2786.3 \mathrm{Da})$, and Thuricin 4A-4D (MW = 2886.3 Da) (Xin et al., 2015). We thus believe that the Subtilin L-Q11 produced by L-Q11 is a novel Class I bacteriocin.

For the food industry, pasteurization and high temperature sterilization are the two commonly used strategies for sterilization (Zhao et al., 2016). The thermostability of Subtilin L-Q11 was tested under the conditions of both pasteurization and high temperature sterilization. Our results showed that after treatment it could preserve more than 96 and $58 \%$ of the antibacterial activity, respectively, compared to the untreated. Therefore, our newly reported bacteriocin showed great utilization potential in the food industry, especially in the dairy industry. This bacteriocin also showed tolerance to a broad range of $\mathrm{pH}$ changes ( $\mathrm{pH} 2.0-9.0$ ), which makes it an excellent food preservative candidate in both acid and alkaline food processing procedures. We also found that the activity of the bacteriocin could be completely destroyed by human digestive enzymes, such as pepsin, trypsin, and chymotrypsin. In other words, the bacteriocin can be decomposed in vivo and is thus safe to human health (Hu et al., 2013). Nevertheless, more in vivo toxicity experiments should be carried out in the future to confirm the biosafety of the bacteriocin.

We showed that the amount of the important human opportunistic pathogen and food contaminating bacterium S. aureus ATCC 29213 decreased 100 -fold from $10^{8}$ to $10^{6} \mathrm{cfu} / \mathrm{mL}$ after $3 \mathrm{~h}$ treatment by Subtilin L-Q11. The molecular mechanism of the killing of S. aureus ATCC 29213 by this new bacteriocin remains unknown. Some of the previously published results 
showed that one of the major killing mechanisms by some Class I bacteriocins is the disruption of the membrane integrity. Those bacteriocins may cause tiny pores on the bacterial cell membrane (Ennahar et al., 2000; Perez et al., 2014). To further investigate the antibacterial mechanism of Subtilin L-Q11, SEM and TEM were used to show the impacts of Subtilin L-Q11 on the ultra cell structures of S. aureus ATCC 29213. The TEM results showed that the intracellular organization of S. aureus ATCC 29213 cells upon bacteriocin treatment was seriously damaged, which likely led to cell death (Figure 7). Under SEM, we observed relatively modest changes in S. aureus ATCC 29213 cell morphology (Figure 6). Cell membrane damage and leak of biomass from the cytoplasm were clearly observed in bacteriocin treated S. aureus ATCC 29213 cells; some cells were even partially lysed. Our observations were also consistent to those previously observed by other bacteriocins. For example, similar cytoplasm damages were reported in nisin and pediocin treated bacteria cells (Kalchayanand et al., 2004; Pattanayaiying et al., 2014). Since membrane damage caused by the pore-forming compounds would lead to severe membrane permeability and leak of the biomass, imbalance of inner and outer membrane (Liu et al., 2017), we believe that the antibacterial mode of action of Subtilin L-Q11 can be further investigated by measuring bacterial membrane potential, intracellular ATP levels, and electric conductivity before and after treatment. Meanwhile, the transcriptomic and proteomic data may also help us to reveal the antibacterial mechanism at the global transcriptional and translational levels. These are ongoing investigations currently in the lab.

\section{REFERENCES}

An, Y., Wang, Y., Liang, X. Y., Yi, H. X., Zuo, Z. H., Xu, X. X., et al. (2017). Purification and partial characterization of M1-UVs300, a novel bacteriocin produced by Lactobacillus plantarum isolated from fermented sausage. Food Control 81, 211-217. doi: 10.1016/j.foodcont.2017.05.030

Barbosa, J., Caetano, T., and Mendo, S. (2015). Class I and Class II lanthipeptides produced by Bacillus spp. J. Nat. Prod. 78, 2850-2866. doi: 10.1021/np500424y

Bressollier, P., Brugo, M. A., Robineau, P., Schmitter, J. M., Sofeir, M., Urdaci, M. C., et al. (2014). "Peptide compound with biological activity, its preparation and its applications". Google Patents.

Cotter, P. D., Hill, C., and Ross, R. P. (2005). Bacterial lantibiotics: strategies to improve therapeutic potential. Curr. Protein Pept. Sci. 6, 61-75. doi: 10.2174/ 1389203053027584

Deraz, S. F., Karlsson, E. N., Hedstrom, M., Andersson, M. M., and Mattiasson, B. (2005). Purification and characterisation of acidocin D20079, a bacteriocin produced by Lactobacillus acidophilus DSM 20079. J. Biotechnol. 117, 343-354. doi: 10.1016/j.jbiotec.2005.02.005

Deraz, S. F., Karlsson, E. N., Khalil, A. A., and Mattiasson, B. (2007). Mode of action of acidocin D20079, a bacteriocin produced by the potential probiotic strain, Lactobacillus acidophilus DSM 20079. J. Ind. Microbiol. Biotechnol. 34, 373-379. doi: 10.1007/s10295-007-0206-8

Dischinger, J., Chipalu, S. B., and Bierbaum, G. (2014). Lantibiotics: promising candidates for future applications in health care. Int. J. Med. Microbiol. 304, 51-62. doi: 10.1016/j.ijmm.2013.09.003

Ennahar, S., Sashihara, T., Sonomoto, K., and Ishizaki, A. (2000). Class IIa bacteriocins: biosynthesis, structure and activity. FEMS Microbiol. Rev. 24, 85-106. doi: 10.1111/j.1574-6976.2000.tb00534.x

Fuchs, S. W., Jaskolla, T. W., Bochmann, S., Kotter, P., Wichelhaus, T., Karas, M., et al. (2011). Entianin, a novel subtilin-like lantibiotic from Bacillus subtilis

\section{CONCLUSION}

In conclusion, Subtilin L-Q11 not only can inhibit the growth of different types of food-borne pathogens but also show great biophysical characteristics such as thermostability, $\mathrm{pH}$-tolerance, resistance to chemical reagents, and sensitivity to various human proteases. Our results suggest that Subtilin L-Q11 has great potential in both the food industry and the agricultural field, as a new biological food preservative and an antibacterial drug.

\section{DATA AVAILABILITY}

The datasets generated for this study can be found in Genbank, MK156679.

\section{AUTHOR CONTRIBUTIONS}

YQ, QMS, and PL designed the experiments. YQ, YW, YH, YZ, and QXS performed the experiments. YQ and YW analyzed the results. YQ and YC wrote the manuscript.

\section{FUNDING}

This work was supported by the Special Fund for Agro-scientific Research in the Public Interest of China (201303014) and a scholarship to YQ from the China Scholarship Council (file No. 201606350112).

subsp. spizizenii DSM 15029T with high antimicrobial activity. Appl. Environ. Microbiol. 77, 1698-1707. doi: 10.1128/AEM.01962-10

Garneau, S., Martin, N. I., and Vederas, J. C. (2002). Two-peptide bacteriocins produced by lactic acid bacteria. Biochimie 84, 577-592. doi: 10.1016/S03009084(02)01414- 1

Giessen, T. W., and Marahiel, M. A. (2012). Ribosome-independent biosynthesis of biologically active peptides: application of synthetic biology to generate structural diversity. FEBS Lett. 586, 2065-2075. doi: 10.1016/j.febslet.2012. 01.017

Grenier, F., Matteau, D., Baby, V., and Rodrigue, S. (2014). Complete genome sequence of Escherichia coli BW25113. Genome Announc. 2:e01038-14. doi: 10.1128/genomeA.01038-14

Hu, M., Zhao, H., Zhang, C., Yu, J., and Lu, Z. (2013). Purification and characterization of plantaricin 163, a novel bacteriocin produced by Lactobacillus plantarum 163 isolated from traditional chinese fermented vegetables. J. Agric. Food Chem. 61, 11676-11682. doi: 10.1021/ jf403370y

Kalchayanand, N., Dunne, P., Sikes, A., and Ray, B. (2004). Viability loss and morphology change of foodborne pathogens following exposure to hydrostatic pressures in the presence and absence of bacteriocins. Int. J. Food Microbiol. 91, 91-98. doi: 10.1016/S0168-1605(03)00324-6

Kanmani, P., Satish, K. R., Yuvaraj, N., Paari, K. A., Pattukumar, V., and Arul, V. (2013). Probiotics and its functionally valuable products-a review. Crit. Rev. Food Sci. Nutr. 53, 641-658. doi: 10.1080/10408398.2011. 553752

Klaenhammer, T. R. (1988). Bacteriocins of lactic-acid bacteria. Biochimie 70, 337-349. doi: 10.1016/0300-9084(88)90206-4

Lane, D. J. (1991). “16S/23S rRNA Sequencing," in Nucleic Acid Techniques in Bacterial Systematics, eds E. Stackebrandt and M. Goodfellow (New York, NY: John Wiley and Sons), 115-175. 
Linares, D. M., Kok, J., and Poolman, B. (2010). Genome sequences of Lactococcus lactis MG1363 (Revised) and NZ9000 and comparative physiological studies. J. Bacteriol. 192, 5806-5812. doi: 10.1128/JB.00533-10

Liu, G., Ren, G., Zhao, L., Cheng, L., Wang, C., and Sun, B. (2017). Antibacterial activity and mechanism of bifidocin a against Listeria monocytogenes. Food Control 73, 854-861. doi: 10.1016/j.foodcont.2016.09.036

Pattanayaiying, R., H-Kittikun, A., and Cutter, C. N. (2014). Effect of lauric arginate, nisin $\mathrm{Z}$, and a combination against several food-related bacteria. Int. J. Food Microbiol. 188, 135-146. doi: 10.1016/j.ijfoodmicro.2014.07.013

Perez, R. H., Zendo, T., and Sonomoto, K. (2014). Novel bacteriocins from lactic acid bacteria (LAB): various structures and applications. Microb. Cell Fact. 13(Suppl 1):S3. doi: 10.1186/1475-2859-13-S1-S3

Phelan, R., Barret, M., Cotter, P. D., Connor, P. D., Chen, R., Morrissey, J. P., et al. (2013). Subtilomycin: a new lantibiotic from Bacillus subtilis strain MMA7 isolated from the marine sponge Haliclona simulans. Mar. Drugs 11, 1878-1898. doi: $10.3390 / \mathrm{md} 11061878$

Qin, Y. X., Han, Y. Z., Shang, Q. M., and Li, P. L. (2015a). Complete genome sequence of Bacillus amyloliquefaciens L-H15, a plant growth promoting rhizobacteria isolated from cucumber seedling substrate. J. Biotechnol. 200, 59-60. doi: 10.1016/j.jbiotec.2015.02.020

Qin, Y. X., Han, Y. Z., Yu, Y. Q., Shang, Q. M., Zhang, B., and Li, P. L. (2015b). Complete genome sequence of Bacillus amyloliquefaciens L-S60, a plant growthpromoting and antifungal bacterium. J. Biotechnol. 212, 67-68. doi: 10.1016/j. jbiotec.2015.08.008

Riley, M. A., and Wertz, J. E. (2002). Bacteriocins: evolution, ecology, and application. Ann. Rev. Microbiol. 56, 117-137. doi: 10.1146/annurev.micro.56. 012302.161024

Singh, P. K., Chittpurna, Ashish, Sharma, V., Patil, P. B., and Korpole, S. (2012). Identification, purification and characterization of Laterosporulin, a Novel bacteriocin produced by Brevibacillus sp. Strain GI-9. PLoS One 7:e31498. doi: 10.1371/journal.pone.0031498

Stein, T. (2005). Bacillus subtilis antibiotics: structures, syntheses and specific functions. Mol. Microbiol. 56, 845-857. doi: 10.1111/j.1365-2958.2005.04587.x

Stein, T., Borchert, S., Conrad, B., Feesche, J., Hofemeister, B., Hofemeister, J., et al. (2002). Two different lantibiotic-like peptides originate from the ericin gene cluster of Bacillus subtilis A1/3. J. Bacteriol. 184, 1703-1711. doi: 10.1128/JB. 184.6.1703-1711.2002
Tagg, J. R., Dajani, A. S., and Wannamaker, L. W. (1976). Bacteriocins of grampositive bacteria. Bacteriol. Rev. 40, 722-756.

Wang, Y., Qin, Y. X., Xie, Q., Zhang, Y., Hu, J. R., and Li, P. L. (2018). Purification and Characterization of plantaricin LPL-1, a novel class IIa bacteriocin produced by Lactobacillus plantarum LPL-1 isolated from fermented fish. Front. Microbiol. 9:2276. doi: 10.3389/fmicb.2018.02276

Wheeler, E. E., Gavin, J. B., and Seelye, R. N. (1975). Freeze-drying from tertiary butanol in the preparation of endocardium for scanning electron microscopy. Stain Technol. 50, 331-337. doi: 10.3109/105202975091 17083

Xin, B., Zheng, J., Xu, Z., Song, X., Ruan, L., Peng, D., et al. (2015). The Bacillus cereus group is an excellent reservoir of novel lanthipeptides. Appl. Environ. Microbiol. 81, 1765-1774. doi: 10.1128/AEM.03758-14

Yamanaka, M., Hara, K., and Kudo, J. (2005). Bactericidal actions of a silver ion solution on Escherichia coli, studied by energy-filtering transmission electron microscopy and proteomic analysis. Appl. Environ. Microbiol. 71, 7589-7593. doi: 10.1128/AEM.71.11.7589-7593.2005

Yang, S. C., Lin, C. H., Sung, C. T., and Fang, J. Y. (2014). Antibacterial activities of bacteriocins: application in foods and pharmaceuticals. Front. Microbiol. 5:241. doi: $10.3389 /$ fmicb.2014.00241

Zhao, S., Han, J., Bie, X., Lu, Z., Zhang, C., and Lv, F. (2016). Purification and characterization of plantaricin JLA-9: a novel bacteriocin against Bacillus spp. produced by Lactobacillus plantarum JLA-9 from Suan-Tsai, a traditional chinese fermented cabbage. J. Agric. Food Chem. 64, 2754-2764. doi: 10.1021/ acs.jafc. 5 b05717

Conflict of Interest Statement: The authors declare that the research was conducted in the absence of any commercial or financial relationships that could be construed as a potential conflict of interest.

Copyright (c) 2019 Qin, Wang, He, Zhang, She, Chai, Li and Shang. This is an open-access article distributed under the terms of the Creative Commons Attribution License (CC BY). The use, distribution or reproduction in other forums is permitted, provided the original author(s) and the copyright owner(s) are credited and that the original publication in this journal is cited, in accordance with accepted academic practice. No use, distribution or reproduction is permitted which does not comply with these terms. 